\section{Simple and effective method for generating single-stranded DNA targets and probes}

\author{
Xing Tang, Sheldon L. Morris, John J. Langone, and Larry E. Bockstahler \\ U.S. Food and Drug Administration, Rockville, MD, USA \\ BioTechniques 40:759-763 (June 2006) \\ doi $10.2144 / 000112154$
}

A simple and efficient PCR method was developed for generating dye-or radiolabeled singlestranded DNA targets or probes used for hybridization studies. The method involved the use of a pair of long primers with high annealing temperatures and a short, labeled primer with a low annealing temperature in a PCR consisting of two cycles at different temperatures. We used this method to generate dye $C y^{\mathrm{TM}} 5$-labeled and $\left[{ }^{32} P\right]$-radiolabeled single-stranded DNA targets and probes. These labeled probes were used successfully for the microarray identification of point mutations in Mycobacterium tuberculosis genes and for the Northern blot detection of expression changes of the GATA-2 gene in Pneumocystis carinii-infected rat lungs.

\section{INTRODUCTION}

The creation of amplification methods to generate single-stranded DNA $(1,2)$ has represented a major advance in development of PCR technology. Single-stranded DNA has been shown to be very useful for DNA hybridization studies (3) with a highly efficient hybridization and no need to be denatured before hybridization. Single-stranded target DNAs have been efficiently used in the studies of microarray hybridization (4-7) and direct sequencing of DNA $(1,8)$.

Single-stranded DNA can be generated by conventional asymmetric or real-time asymmetric PCR $(9,10)$. Alternative methods of generating single-stranded DNA targets and probes include the utilization of biotin-streptavidin purification procedures $(11,12)$. However, many of the methods of single-stranded DNA generation require extra steps to process the products and thus are timeconsuming and costly. Conventional asymmetric PCR procedures using an unequal concentration of the forward and reverse amplification primers are theoretically simple (13), but they did not give us satisfactory results as other researchers have indicated (10).

The purpose of this study was to develop an improved asymmetric PCR procedure for generating singlestranded DNA. This novel method used a unique PCR nesting approach to generate single-stranded DNA probes. We demonstrated that these probes were effective for the DNA hybridizations associated with two different molecular biology procedures. The single-stranded DNA targets that we generated were used for the microarray detection of mutations in several drug-resistant strains of Mycobacterium tuberculosis. We also generated single-stranded DNA probes for use with a Northern blot procedure involving detection of the expression of a transcription factor, GATA-2, associated with Pneumoncystis carinii infection. Overall, the method that we developed for asymmetric PCR generation of labeled, single-stranded probes or targets is relatively easy to perform and was effectively utilized to create DNA probes for two different biological assays.

\section{MATERIALS AND METHODS}

\section{Oligonucleotide Primers and Probes}

The design of PCR primers and probes used for microarray analysis was based on the published genome sequence of $M$. tuberculosis (14) and published data on the M. tuberculosis gene mutations associated with drug resistance (15). The DNA primers and amine-linked probes were synthe- sized by the Center for Biologics Evaluation and Research's Facility for Biotechnology Resources (U.S. Food and Drug Administration, Rockville, MD, USA). They were prepared with a Model 394 automated DNA synthesizer (Applied Biosystems, Foster City, CA, USA) using cyanoethyl phosphoramidite nucleosides. The probes we designed and used for microarray studies included wild-type AOK463: 5'-TCCCGATGCCCGGATCTG-3'; mutant AOK463: 5'-TCCCGATGCC AGGATCTG-3'; wild-type AOK587: 5'-GCTCCAGCACGGCAAAGG-3'; and mutant AOK587: 5'-GCTCCA TCACGGCAAAGG-3'.

\section{Asymmetric PCR for Microarray Analyses}

Double-stranded DNA templates containing point mutations in the $M$. tuberculosis gene katG were prepared by a recombinant PCR in vitro mutagenesis technique (16-18). Single-stranded DNA targets were then generated by our asymmetric PCR technique (Figure 1). This technique used three primers in a PCR. Two paired primers (forward and reverse), with a high annealing temperature $\left(70^{\circ} \mathrm{C}\right)$ and a very low concentration ( 1 pmol/40 $\mu \mathrm{L}$ ), were used for the generation of a small amount of primary doublestranded PCR product in the first round of PCR. A short Cy ${ }^{\mathrm{TM} 5}$-labeled third primer, with a much lower annealing temperature $\left(54^{\circ} \mathrm{C}\right)$ and a high concentration $(15 \mathrm{pmol} / 40 \mu \mathrm{L})$, was designed to nest inside of the products generated in the first round of PCR to create single-stranded targets or probes in the second round of PCR. The forward and reverse primers, MTB-Kf2 (5'-CAAG CTGATCCACCGAGACATG-3') and MTB-Kr2 (5'-CTTGTCGAG CAGCATGTACTCG-3'), were used to generate a 610-bp PCR fragment containing codon positions of 463 and 578 in the katG gene. The Cy5labeled third primer, Cy5-Kf2s (5' ATCCACCGAGACATGG-3'), nested inside of the PCR product generated by MTB-Kf2 and MTB-Kr2. For M. tuberculosis mutation detection, each $40 \mu \mathrm{L}$ of PCR solution consisted of PCR buffer $(2 \mathrm{mM}$ Tris- $\mathrm{HCl}, \mathrm{pH}$ 8.0, $1.5 \mathrm{mM} \mathrm{MgCl}_{2}, 10 \mathrm{mM} \mathrm{KCl}$, 


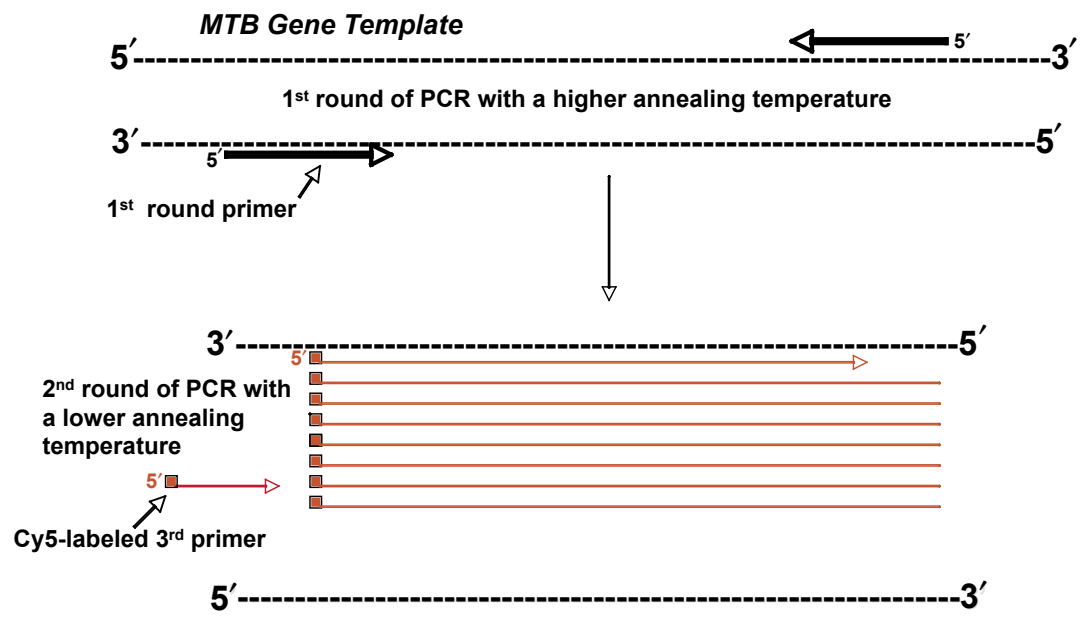

Figure 1. Generation of single-stranded DNA products (targets). The method is composed of two rounds of PCR and uses three primers that exist in a single tube during the whole reaction. A pair of primers with a high annealing temperature $\left(70^{\circ} \mathrm{C}\right)$ and a very low concentration $(1 \mathrm{pmol} / 40 \mu \mathrm{L})$ is used in the first round of PCR to generate a small amount of double-stranded DNA fragments. A Cy5-labeled third primer with a much lower annealing temperature $\left(54^{\circ} \mathrm{C}\right)$ and a high concentration $(15 \mathrm{pmol} / 40$ $\mu \mathrm{L}$ ) is used in the second round of PCR. The third primer nests inside of the products created in the first round of PCR and uses the products as templates to generate single-stranded targets or probes.

$10 \mathrm{mM}$ EDTA), $200 \mu \mathrm{M}$ each dNTP, 1 pmol each forward and reverse primers, 15 pmol Cy5-labeled third primer, 50-60 pg recombinant PCRgenerated template, and $2 \mathrm{U}$ Takara Taq DNA polymerase (Takara Mirus Bio, Madison, WI, USA). The cycling program was $94^{\circ} \mathrm{C}$ for 3 min for DNA denaturation, followed by 20 cycles of $94^{\circ} \mathrm{C}$ for $20 \mathrm{~s}$, and $70^{\circ} \mathrm{C}$ for $90 \mathrm{~s}$. This was followed immediately by 20 cycles of $94^{\circ} \mathrm{C}$ for $20 \mathrm{~s}, 54^{\circ} \mathrm{C}$ for 20 $\mathrm{s}$, and $72^{\circ} \mathrm{C}$ for $1 \mathrm{~min}$. To test whether the PCR products consisted of singlestranded DNA, the PCR product was treated with S1 nuclease $(20 \mu \mathrm{L}$ PCR product $/ 20 \mathrm{U}$ S1 nuclease at $37^{\circ} \mathrm{C}$ for $30 \mathrm{~min}$ ). Doubled-stranded PCR

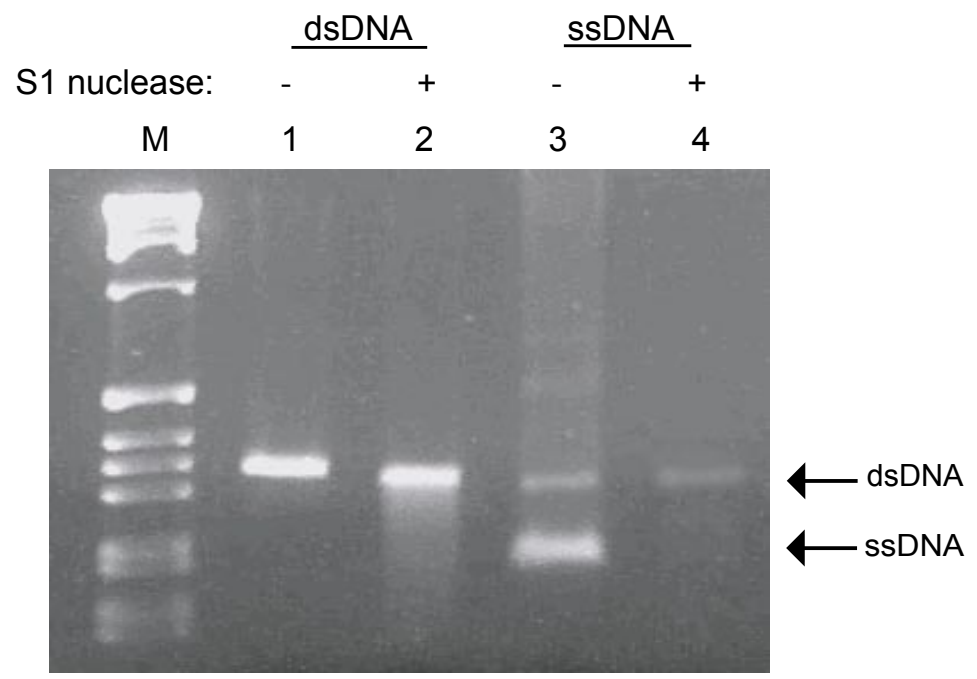

Figure 2. Agarose gel electrophoresis of double-stranded PCR product and single-strand PCR product treated with S1 nuclease. Lanes 1 and 2 were loaded with S1 nuclease untreated (-) and treated $(+)$ double-stranded PCR products, respectively; lanes 3 and 4 were loaded with S1 nuclease untreated (-) and treated $(+)$ PCR products generated by our method, respectively. After the treatment with S1 nuclease, single-stranded PCR products (ssDNA in lane 3) are degraded (lane 4), whereas double-stranded PCR products (dsDNA in lanes 1 and 3) remained intact (lanes 2 and 4). The gel was stained with ethidium bromide. product generated with the first pair of primers was also treated at the same conditions as a comparison. Five microliters of each treated and untreated PCR product were electrophoresed side-byside on a $1 \%$ regular agarose gel in TBE buffer (Roche, Indianapolis, IN, USA) at $150 \mathrm{~V}$ to compare the existence of single-stranded fragments. The gel was stained with ethidium bromide in TBE buffer for $30 \mathrm{~min}$ before photography under UV light. All the PCR-generated products to be used for hybridization (targets) were mixed together, purified by ethanol precipitation, and dissolved in $60 \mu \mathrm{L}$ distilled water.

\section{Asymmetric PCR for Northern Blot Analyses}

For the GATA-2 expression experiments, the paired forward and reverse primers designed and used to generate a 390-bp PCR fragment were GATAratF (5'-GGCAAAGCAGCTCTCTCTGC-3') and GATAratR (5' GGACTGCCACCTTCCATCTTC-3'). A $\left.{ }^{32} \mathrm{P}\right]$-labeled third primer, GATAratF2 (5'-TCTCTCTGCCGCTGC-3'), was used to generate a radiolabeled singlestranded DNA probe using the 390-bp fragment as a template generated in the first round of PCR. Each $40 \mu \mathrm{L}$ of PCR solution consisted of PCR buffer, $200 \mu \mathrm{M}$ each dNTP, $1.5 \mathrm{mM} \mathrm{MgCl}_{2}$, 1 pmol each forward and reverse primers, 15 pmol third primer, 50-60 pg cloned GATA-2 template, and 2 U Takara Taq DNA polymerase. The cycling program was $94^{\circ} \mathrm{C}$ for $3 \mathrm{~min}$, followed by 20 cycles of $94^{\circ} \mathrm{C}$ for 20 $\mathrm{s}$ and $70^{\circ} \mathrm{C}$ for $90 \mathrm{~s}$. This was followed immediately by 20 cycles of $94^{\circ} \mathrm{C}$ for $20 \mathrm{~s}, 54^{\circ} \mathrm{C}$ for $20 \mathrm{~s}$, and $72^{\circ} \mathrm{C}$ for 1 $\mathrm{min}$. The PCR-generated radioactive probes were purified by Sephadex ${ }^{\circledR}$ G-50 column and eluted into $60 \mu \mathrm{L}$ distilled water and mixed with hybridization solution.

\section{Microarray Spotting of DNA Probes}

The M. tuberculosis wild-type and mutant probes were spotted onto CSS-silylated glass microscope slides (Fisher Scientific, Hampton, NH, USA) with an OmniGrid Accent ${ }^{\mathrm{TM}}$ robotic microarrayer (Genomic 
Solutions, Ann Arbor, MI, USA). Each probe $(100 \mu \mathrm{M})$ was mixed $1: 1$ with microarray spotting solution consisting of $100 \mathrm{mM} \mathrm{NaOH}$ and $0.02 \%$ sodium dodecyl sulfate (SDS).

The average spot size was $200 \mu \mathrm{m}$. Each probe was spotted in triplicate, and the distance between spots was $500 \mu \mathrm{m}$. The spotted slides were left overnight at room temperature in a clean chamber for drying.

\section{Rat Lung Total RNA Isolation and Northern Blot Analysis}

The total RNA was isolated from normal and $P$. carinii-infected rat lungs by the acid guanidinium thiocyanate-phenol-chloroform extraction method (19). Fifteen micrograms of each isolated total RNA sample were electrophoresed on an RNA gel and then transferred to a Nitran membrane (Schleicher \& Schuell, Keene, NH, USA). The transferred membrane was UV-linked and baked at $80^{\circ} \mathrm{C}$ for $1 \mathrm{~h}$.
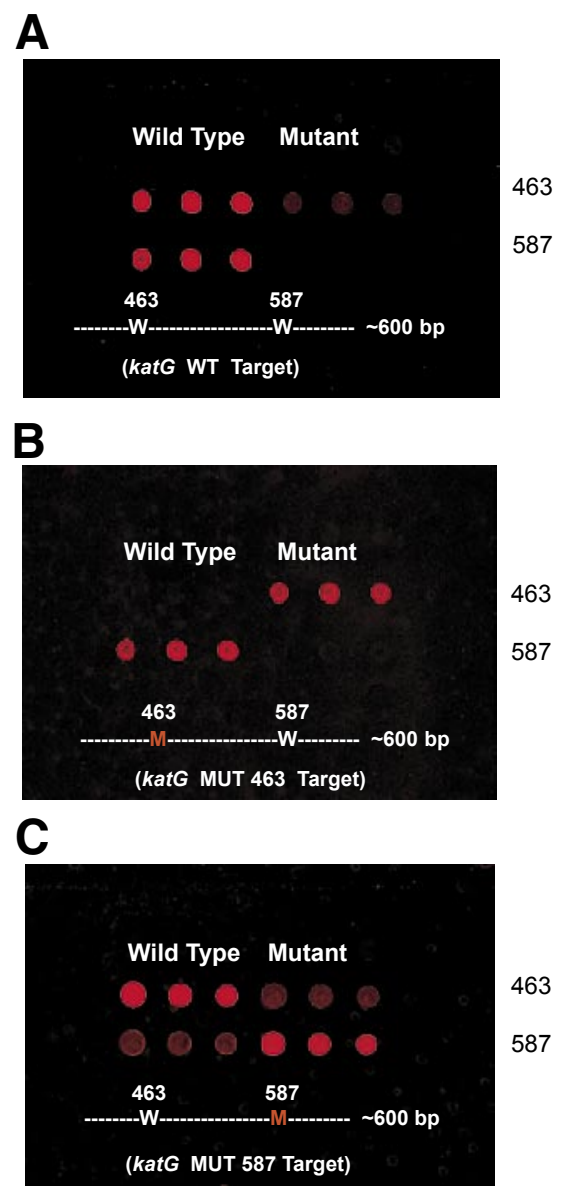

\section{Hybridization for Microarray Analysis}

Ten microliters purified Cy5-labeled targets were mixed with an equal volume of hybridization solution consisting of $50 \%$ formamide, $10 \times$ saline sodium citrate (SSC), $0.2 \%$ SDS and $0.2 \mathrm{mg} / \mathrm{mL}$ sperm DNA and were added to the probe area on the slide. A coverslip was added, and the slides were kept in a humidified chamber at $40^{\circ} \mathrm{C}$ for $30 \mathrm{~min}$ for hybridization. The slides were subsequently washed with a series of solutions that descended from $6 \times$ SSC to $2 \times$ SSC for $2 \mathrm{~min}$ each at room temperature. The hybridization signals on the slides were visualized with a GenePix ${ }^{\circledR}$ 4000B Array Scanner (Axon Instruments, Union City, CA, USA) at $635 \mathrm{~nm}$.

\section{Hybridization for Northern Blot Analysis}

The $\left.{ }^{32} \mathrm{P}\right]$-labeled GATA-2 singlestranded DNA probe was added directly

Figure 3. Oligonucleotide microarray identification of Mycobacterium tuberculosis $k a t G$ gene point mutations. This figure shows a copy of the actual scanner hybridization results from the microarray experiment. Each microarray $(\mathrm{A}-\mathrm{C})$ consisted of 12 DNA oligomeric probe spots. Four different probes (two wild-type and two mutant) were each spotted in triplicate on a glass slide. The wild-type probes contained all wild-type $k a t G$ codons, and the mutant probes contained wild-type $k a t G$ codons plus one $k a t G$ codon (463 or 587) with a point mutation. The target DNAs used in this experiment were all single-stranded, generated by asymmetric PCR. The label at the top of each subfigure indicates the particular target DNA used for hybridization with the spotted probes. It includes the $M$. tuberculosis gene plus, in the case of targets with a point mutation, the particular mutant codon selected. A simple representation of the target DNA is presented at the bottom of each subfigure and identifies the relevant codons used in the experiment and whether or not each codon is wild-type (W) or mutant (M). Target DNAs used were (A) katG WT Target, which consisted of all wild-type $k a t G$ codons (including 463 and 587), (B) katG 463 MUT Target, which consisted of one wild-type $k a t G$ codon 587 plus one $k a t G$ codon 463 (a polymorphism) with a point mutation, and (C) $k a t G 587$ MUT Target, which consisted of the one wild-type $k a t G$ codon 463 plus one $k a t G$ codon 587 with a point mutation. The numbers in the column on the right side of each subfigure represent the two $k a t G$ codons of the spotted probes that were designed to be complementary to the selected sequences of interest in the target DNAs. This figure shows that the asymmetric PCR-generated, single-stranded target DNAs successfully hybridized with the probes. into a hybridization bag containing a blotted membrane plus hybridization solution consisting of $0.25 \mathrm{M}$ phosphate buffer, $\mathrm{pH} 7.0,7 \%$ SDS, and $1 \mathrm{mM}$ EDTA. The hybridization bag was kept in a shaking water incubator at $65^{\circ} \mathrm{C}$ for $16 \mathrm{~h}$. After hybridization, the membrane was washed with a series of washing solutions that descended from $2 \times \mathrm{SSC}, 0.5 \%$ SDS to $0.5 \times \mathrm{SSC}, 0.1 \%$ $\mathrm{SDS}$, each at $65^{\circ} \mathrm{C}$ for $20 \mathrm{~min}$. The hybridization signal of GATA-2 was visualized by exposure of an X-ray film at $-80^{\circ} \mathrm{C}$ for $72 \mathrm{~h}$.

\section{RESULTS AND DISCUSSION}

Figure 2 shows the results of double-stranded and single-stranded PCR fragments treated with S1 nuclease. The single-stranded fragment (the product in the second round of PCR) showed a lower position on the gel due to its smaller molecule size as compared with that of the doublestranded fragment (the product in the first round of PCR). After treatment with S1 nuclease (as shown in Figure 2 ), the single-stranded fragment was degraded, while the double-stranded fragment remained almost intact.

Experiments were subsequently performed to show that this asymmetric PCR procedure generated singlestranded DNA targets and probes that were effective in hybridization studies. Three different Cy5-labeled, singlestranded target DNAs containing katG gene sequences were prepared by our method. One of these, $k a t G \mathrm{WT}$, contained a wild-type $k a t G$ sequence that included codons 463 and 587. The other two target DNAs each contained one point mutation at either position 463 ( $\mathrm{G}$ to $\mathrm{T}$ ) or 587 (C to $\mathrm{A}$ ) and were also prepared by the same methods. The details of probe arrangement on the slide are given in the legend of Figure 3.

Each of the three single-stranded target DNAs was hybridized to a microarray containing the four immobilized probes. Figure 3 shows a typical example of the hybridization data obtained. In Figure 3A, katG WT target DNA was hybridized with the four probes. As expected, hybridization of this target DNA occurred with 
wild-type probes 463 and 587. Little or no hybridization was observed with mutant probes 463 and 587. Results for the remainder of the experiment were similar. As expected, Figure 3B shows that the katG 463 MUT target DNA hybridized with the mutant 463 probe, but not with the wild-type 463 probe. Since this target DNA contained wildtype codon 587, it hybridized with the wild-type probe 587 , but not with the mutant probe 587. Figure 3C shows similar data: the katG 587 MUT target DNA hybridized best with the probe that contained the 587 point mutant anticodon and the probe that contained the wild-type 463 anticodon. Some minor nonspecific hybridization was observed with the 463 mutant probe and the 587 wild-type probe.

To further demonstrate the utility of our asymmetric PCR procedure, singlestranded probes were generated to detect expression of the gene of GATA transcription factor in the host infected by $P$. carinii (20-22) using Northern blot analysis. For Northern blotting, a high quality of labeled probes is critical for the successful detection of messenger RNAs (mRNAs) with low copy numbers such as transcription factors and kinases. After treatment, the membrane was hybridized with a single-stranded radiolabeled GATA2 DNA probe that was generated by asymmetric PCR. The hybridization results are shown in Figure 4. A clear radioactive signal band was observed in the first lane (control), where the total RNA from normal rat lungs had been loaded. However, no band was observed in lane 2 (infected), which had been loaded with RNA from $P$. carinii infected rat lungs.

Overall, we have shown that the single-stranded DNA targets and probes prepared by an improved asymmetric PCR method can be successfully used in hybridization reactions without the need for a denaturation step. Since there is no competition of antisense strands in hybridization solutions, single-stranded probes can find their targets on the membrane, array, or chip much better than conventional PCR products, which are double-stranded. As compared with conventional asymmetric PCR methods, our protocol used a third primer that was seated inside the PCR fragment generated by the first round of PCR; a second round of PCR was performed like a nested PCR, which usually has higher amplification efficiency than regular PCR. Moreover, as compared with other more complicated methods for generation of single-strand fragments, our method is simpler and more straightforward. All of the preparation is completed in a single tube with a PCR program that combines two rounds of PCR. The targets/probes prepared using this method contained a very small amount of double-stranded PCR product (first round of PCR), but they should not interfere with the hybridization without a denaturing step. In summary, we have developed a straightforward and effective asymmetric PCR protocol that can be easily adapted for other studies in which efficient hybridization procedures are required.

\section{COMPETING INTERESTS STATEMENT}

The authors declare no competing interests.

\section{REFERENCES}

1. Gyllensten, U.B. and H.A. Erlich. 1988. Generation of single-stranded DNA by the polymerase chain reaction and its application to direct sequencing of the $H L A-D Q A$ locus. Proc. Natl. Acad. Sci. USA 85:7652-7656.

2. McCabe, P.C. 1990. Production of singlestranded DNA by asymmetric PCR, p. 76. In M.A. Innis, D.H. Gelfand, and J.J. Sninsky (Eds.), PCR Protocols, A Guide to Methods and Applications. Academic Press, New York.

3. Scully, S.P., M.E. Joyce, N. Abidi, and M.E. Bolander. 1990. The use of polymerase chain reaction generated nucleotide sequences as probes for hybridization. Mol. Cell. Probes 4:485-495.

4. Wang, D., Y. Li, R. Zhang, D. Jiang, X. Ma, Y. Zhou, and J. Cheng. 2003. Detection of known mutations in hypertrophic cardiomyopathy using oligonucleotide microarrays assisted by improved base stacking hybridization. Biotechnol. Lett. 25:1613-1618.

5. Wang, D., H. Gao, R. Zhang, X. Ma, Y. Zhou, and J. Cheng. 2003. Single nucleotide polymorphism discrimination assisted by improved base stacking hybridization using oligonucleotide microarrays. BioTechniques 35:300-308

6. Mahalingam, R. and N. Fedoroff. 2001. Screening insertion libraries for mutations

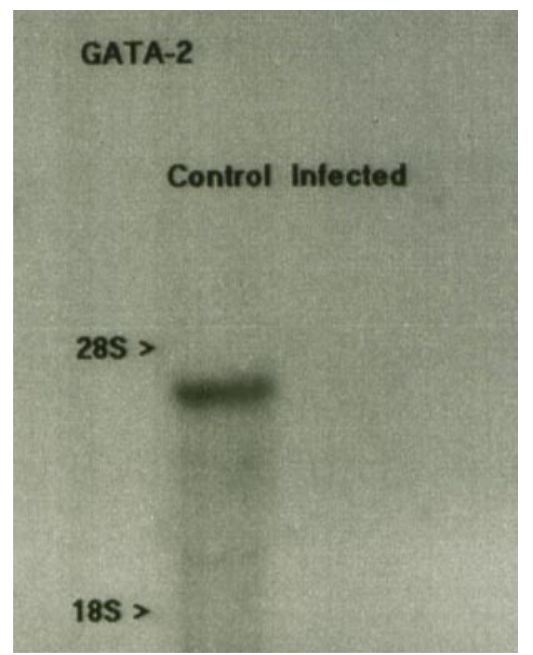

Figure 4. Northern blot analysis of rat GATA2 gene. Representative autoradiogram showing Northern blot analysis of total RNA isolated from normal and Pneumoncystis carinii-infected rat lungs using a $\left[{ }^{32} \mathrm{P}\right] \mathrm{dCTP}$-labeled single-stranded DNA oligonucleotide probe. The control lane represents analysis of RNA from uninfected rat lungs. The infected lane represents analysis of RNA from $P$. carinii-infected rat lungs. Size markers show the location of $28 \mathrm{~S}$ and $18 \mathrm{~S}$ rat ribosomal RNA. As expected, the position of the GATA-2 mesenger RNA (mRNA), as indicated by the hybridization band in the control lane, is about $3000 \mathrm{bp}$. This figure (control lane) shows that the asymmetric PCR-generated DNA probe successfully hybridized with the blotted rat RNA target.

in many genes simultaneously using DNA microarrays. Proc. Natl. Acad. Sci. USA 98:7420-7425.

7. Wei, Q., S. Liu, J. Huang, X. Mao, X. Chu, Y. Wang, M. Qiu, Y. Mao, et al. 2004 Comparison of hybridization behavior between double and single strands of targets and the application of asymmetric PCR targets in cDNA microarray. J. Biochem. Mol. Biol. 37:439-444.

8. Innis, M.A., K.B. Myambo, D.H. Gelfand, and M.A. Brow. 1988. DNA sequencing with Thermus aquaticus DNA polymerase and direct sequencing of polymerase chain reactionamplified DNA. Proc. Natl. Acad. Sci. USA 85:9436-9440.

9. Pierce, K.E., J.E. Rice, J.A. Sanchez, and L.J. Wangh. 2003. Detection of cystic fibrosis alleles from single cells using molecular beacons and a novel method of asymmetric realtime PCR. Mol. Hum. Reprod. 9:815-820.

10. Sanchez, J.A., K.E. Pierce, J.E. Rice, and L.J. Wangh. 2004. Linear-after-the-exponential (LATE)-PCR: an advanced method of asymmetric PCR and its uses in quantitative real-time analysis. Proc. Natl. Acad. Sci. USA 101:1933-1938.

11. Riccelli, P.V., F. Merante, K.T. Leung, S. Bortolin, R.L. Zastawny, R. Janeczko, and A.S. Benight. 2001. Hybridization of singlestranded DNA targets to immobilized complementary DNA probes: comparison of hairpin 
versus linear capture probes. Nucleic Acids Res. 29:996-1004.

12. Chizhikov, V., M. Wagner, A. Ivshina, Y. Hoshino, A.Z. Kapikian, and K. Chumakov. 2002. Detection and genotyping of human group A rotaviruses by oligonucleotide microarray hybridization. J. Clin. Microbiol. 40:2398-2407.

13. Millican, D.S. and I.M. Bird. 1997. A general method for single-stranded DNA probe generation. Anal. Biochem. 249:114-117.

14. Cole, S.T., R. Brosch, J. Parkhill, T. Garnier, C. Churcher, D. Harris, S.V. Gordon, K. Eiglmeier, et al. 1998. Deciphering the biology of Mycobacterium tuberculosis from the complete genome sequence. Nature 393:537-544.

15. Ramaswamy, S. and J.M. Musser. 1998. Molecular genetic basis of antimicrobial agent resistance in Mycobacterium tuberculosis: 1998 update. Tuber. Lung Dis. 79:3-29.

16. Higuchi, R. 1990. Recombinant PCR, p. 177. In M.A. Innis, D.H. Gelfand, and J.J. Sninsky (Eds.), PCR Protocols, A Guide to Methods and Applications. Academic Press, New York.

17. Burns, E.L., R.A. Nicholas, and E.M. Price. 1996. Random mutagenesis of the sheep $\mathrm{Na}, \mathrm{K}$-ATPase alpha1 subunit generating the ouabain-resistant mutant L793P. J. Biol. Chem. 271:15879-15883.

18. Rashtchian, A. 1995. Novel methods for cloning and engineering genes using the polymerase chain reaction. Curr. Opin. Biotechnol. 6:30-36.

19. Chomczynski, P. and N. Sacchi. 1987. Single-step method of RNA isolation by acid guanidinium thiocyanate-phenol-chloroform extraction. Anal. Biochem. 162:156-159.

20. Bouhassira, E.E., M.F. Kielman, J. Gilman, M.F. Fabry, S. Suzuka, O. Leone, E. Gikas, L.F. Bernini, and R.L. Nagel. 1997. Properties of the mouse alpha-globin HS-26: relationship to HS-40, the major enhancer of human alpha-globin gene expression. Am. J. Hematol. 54:30-39.

21. Nagai, T., H. Harigae, H. Ishihara, H. Motohashi, N. Minegishi, S. Tsuchiya, N. Hayashi, L. Gu, et al. 1994. Transcription factor GATA-2 is expressed in erythroid, early myeloid, and CD34+ human leukemia-derived cell lines. Blood 84:1074-1084.

22. Tang, X., M.E. Lasbury, D.D. Davidson, M.S. Bartlett, J.W. Smith, and C.H. Lee. 2000. Down-regulation of GATA-2 transcription factor during Pneumocystis carinii infection. Infect. Immun. 68:4720-4724.

Received 11 August 2005; accepted 9 February 2006.

Address correspondence to Xing Tang, Division of Biology, U.S. Food and Drug Administration, 10903 New Hampshire Ave., Rm 3033, Silver Spring, MD 20903, USA. e-mail:xxt4@cdrh.fda.gov

To purchase reprints

of this article, contact

Reprints@BioTechniques.com 